\title{
PLASMA CONCENTRATIONS OF PROGESTERONE, OESTRONE, OESTRADIOL-17 $\beta$ AND OF OESTRONE SULPHATE IN THE PIG AT IMPLANTATION, DURING PREGNANCY AND AT PARTURITION
}

\author{
H. A. ROBERTSON AND G. J. KING* \\ Reproductive Physiology Section, Animal Research Institute, Ottawa, \\ Canada $K 1 A 0 C 6$, and \\ *Department of Animal and Poultry Science, University of Guelph, \\ Guelph, Canada N1G $2 W 1$ \\ (Received 1st February 1974)
}

\begin{abstract}
Summary. The changes in the plasma levels of progesterone, of unconjugated oestrone and oestradiol-17 $\beta$, and of oestrone sulphate in the sow at the time of implantation, during gestation and at parturition are described. The progesterone concentration remained fairly constant (10 to $12 \mathrm{ng} / \mathrm{ml}$ ) throughout pregnancy until 20 to 15 days before parturition. The progesterone concentration dropped over the last 15 days of gestation. Measurable quantities of oestrone sulphate were present in the maternal plasma at Day 16 but not at Day 9 of gestation and rose to a peak $>3 \mathrm{ng} / \mathrm{ml}$ (assessed as free oestrone) between Day 23 and Day 30. The concentration fell to a low level of $35 \mathrm{pg} / \mathrm{ml}$ on Day 46 before rising to a second peak of $3 \mathrm{ng} / \mathrm{ml}$ just before parturition. Measurable quantities of unconjugated oestrone $(>10 \mathrm{pg} / \mathrm{ml})$ and oestradiol-17 $\beta$ $(>15 \mathrm{pg} / \mathrm{ml}$ ) first appeared in the plasma at approximately Day 70 to Day 80 and their rise to a peak at the time of parturition followed very closely that of oestrone sulphate. Unconjugated oestrone rose to a peak at a mean concentration of $2.5 \mathrm{ng} / \mathrm{ml}$ and oestradiol $-17 \beta$ at $400 \mathrm{pg} / \mathrm{ml}$. No oestradiol-17 $\alpha$ was detected. The concentration of these steroids returned to basal levels by $72 \mathrm{hr}$ after parturition.
\end{abstract}

\section{INTRODUCTION}

No systematic study has, as yet, been reported on the changes in the concentration of progesterone or of the oestrogens present in the plasma of the sow during gestation. Shearer, Purvis, Jenkin \& Haynes (1972) have reported a limited amount of information on the levels of progesterone and unconjugated oestradiol-17 $\beta$ during the early and the later part of gestation, while Molokwu \& Wagner (1973) and Ash, Banks, Bailes, Broad \& Heap (1973) have described changes in the plasma concentration of corticoids, progesterone and unconjugated oestrone and oestradiol-17 $\beta$ over the periods from 8 days before to 8 
days after parturition and from 7 to 12 days before parturition to birth respectively.

In this study, pregnant gilts were bled regularly throughout gestation and the values for the plasma concentration of progesterone, unconjugated oestrone and oestradiol-17 $\beta$ and for oestrone sulphate are reported.

\section{MATERIALS AND METHODS}

\section{Animals}

Six nulliparous Yorkshire gilts mated at 9 months of age were used. The sows were maintained under normal conditions of husbandry throughout the experimental period.

\section{Plasma collection}

For blood withdrawal the animals were restrained by a snout rope when in farrowing crates, or in a hog squeeze at other times. Blood samples were obtained by inserting an 18-gauge, 15- or 20-cm long hypodermic needle through the skin approximately $3 \mathrm{~cm}$ anterolateral to the tip of the sternum. The needle tip was directed upwards and inwards between the first two ribs until it entered the anterior vena cava. Blood was aspirated into a syringe and immediately transferred into a heparinized tube. Samples were cooled quickly by immersing in an ice-water bath and were then centrifuged. The plasma was transferred in 2.5-ml aliquots to glass vials which were sealed and stored at $-20^{\circ} \mathrm{C}$. Most of the plasma samples showed some slight degree of haemolysis which was probably due to erythrocyte fragility during cooling in the ice-water. This phenomenon had not been encountered with plasma samples prepared in a similar manner from blood collected from cattle and sheep.

\section{Progesterone determination}

The concentration of progesterone in plasma was determined by a modification of the competitive protein-binding method using male dog plasma (Murphy, 1964, 1957; Neil, Johansson, Datta \& Knobil, 1967) as described by Robertson \& Sarda (1971) and Robertson (1972).

Specificity. To permit large numbers of samples to be rapidly processed, the time-consuming thin-layer chromatography (TLC) was omitted. This could have resulted in some sacrifice of specificity but results with duplicate samples in which progesterone was estimated with and without TLC demonstrated that the presence of interfering substances in the plasma of the sow at different stages of pregnancy was negligible. Similar observations have been made by Thorburn, Bassett \& Smith (1969) and by Sarda, Robertson \& Smeaton (1973) for the ewe, by Robertson (1972) for the cow and by Johansson (1969) for the human female. All determinations were carried out in duplicate using 0.5or 1-ml aliquots of plasma.

\section{Oestrogen determinations}

Unconjugated oestrogens. Unconjugated oestrone and oestradiol-17 $\beta$ were determined as described by Robertson, Smeaton \& Durnford (1972) using $1 \mathrm{ml}$ 
plasma. The sensitivity of this method has been estimated to be $11 \mathrm{pg}$ for oestrone and $13 \mathrm{pg}$ for oestradiol-17 $\beta$ using one half of the final extract for measuring the recovery of an incorporated internal radioactive standard. All determinations were carried out in duplicate and the values presented have been corrected for procedural losses. Since this method will also measure unconjugated oestradiol-17 $\alpha$, some samples were tested for the presence of oestradiol-17 $\alpha$. As it was impracticable to carry out individual estimates of oestrone and oestradiol- $17 \beta$ on all the plasma samples from the first group of five gilts, pooled samples were made. Before Day 90 , the time of pooling the individual samples was standardized from the time of conception. After Day 90, they were standardized from the time of parturition, taken as Day 114. In order to obtain an estimate of the between-animal variation and to determine the effect, if any, of the number of fetuses, estimates of oestrone and oestradiol$17 \beta$ were carried out on individual plasma samples taken from all animals 9 days before parturition.

Oestrone sulphate determination. The method described by Loriaux, Ruder \& Lipsett (1971) for the measurement of oestrone sulphate in human plasma was used with some modification. Approximately $1500 \mathrm{ct} / \mathrm{min}\left[{ }^{3} \mathrm{H}\right]$ oestrone-3sulphate $(40 \mathrm{Ci} / \mathrm{mmol}$ ), equivalent to $15 \mathrm{pg}$ oestrone sulphate or to $10.7 \mathrm{pg}$ oestrone, was added in $0.1 \mathrm{ml}$ methanol to a $45-\mathrm{ml}$ stoppered centrifuge tube. The methanol was dried under $\mathrm{N}_{2}$ in a water-bath at 40 to $45^{\circ} \mathrm{C}$, the plasma sample $(1 \mathrm{ml})$ was added, followed by $0.1 \mathrm{ml}$ of $0.1 \mathrm{~N}-\mathrm{NaOH}$ and $5 \mathrm{ml}$ of benzene. The plasma was extracted by mixing the contents twice for $1 \mathrm{~min}$ on a vortex mixer, the benzene layer was discarded and the upper portion of the centrifuge tube was rinsed twice with $1 \mathrm{ml}$ benzene which was again discarded. Benzene extraction removes $90 \%$ of the free oestrone (Robertson et al., 1972). A very small fraction $(<5 \%)$ of the $\left[{ }^{3} \mathrm{H}\right]$ oestrone sulphate was extracted from the plasma by the benzene. Following the extraction of the free oestrogens, $2.0 \mathrm{ml}$ of $0.5 \mathrm{M}-\mathrm{NaHCO}_{3}(\mathrm{pH} 8.0$ ) saturated with $\mathrm{NaCl}$ was added and the plasma was extracted twice with $5 \mathrm{ml}$ tetrahydrofuran-ethylacetate, $1: 1 \mathrm{v} / \mathrm{v}$ (Tsang, 1974). After each mixing, the tubes were centrifuged to break the emulsion and the upper phase containing the steroid sulphates was transferred to a 15-ml stoppered tube and dried under $\mathrm{N}_{2}$. The incorporation of an initial benzene extraction step into the procedure to remove the unconjugated oestrogens removes the necessity to separate the free oestrogens from their conjugates by TLC and as a consequence the TLC step was normally omitted. Initially, some extracts were run on TLC using ethylacetate-ethanol-ammonium hydroxide, 5:5:1 by vol. (Sarfaty \& Lipsett, 1966) as described by Loriaux et al. (1971). No difference was found in the estimates for oestrone sulphate in plasma when results with and without the TLC step were compared.

The tetrahydrofuran-ethyl acetate extract, or the dried steroid sulphate fraction from the TLC plate was dissolved in $0.25 \mathrm{ml}$ methanol, $1.0 \mathrm{ml}$ ethylacetate-glacial acetic acid mixture, 9:1 v/v, was added, and the tubes were stoppered and mixed. Solvolysis was carried out overnight (16 hr) in a shaking water-bath at $50^{\circ} \mathrm{C}$. The solvolysis mixture was thoroughly dried under $\mathrm{N}_{2}$, the residue was dissolved in $0.5 \mathrm{ml}$ iso-octane and then transferred to a celite 
column for the separation of unconjugated oestrone from unconjugated oestradiol-17 $\beta$ and other oestrogens (Robertson et al., 1972). Solvolysis of oestrone sulphate was virtually complete and the overall recovery for oestrone sulphate was 60 to $70 \%$ compared with 80 to $85 \%$ for free oestrone. Oestrone3 -glucuronide was not hydrolysed by this solvolysis procedure. The amount of oestrone was then determined by radioimmunoassay as described above. All estimations were carried out in duplicate, were corrected for recovery and have been expressed as oestrone equivalents. To correct for the actual gravimetric amounts of oestrone sulphate, the values should be multiplied by 1.4 .

\section{RESULTS}

Gestation length and litter size

The gestation length and the litter size of the six gilts used in this experiment are shown in Table 1.

Table 1. Gestation length and litter size in the experimental sows

\begin{tabular}{c|c|c}
\hline Gilt no. & $\begin{array}{c}\text { Gestation length } \\
\text { (days) }\end{array}$ & Litter size \\
\hline 1 & 116 & 15 \\
2 & 116 & 9 \\
3 & 113 & 10 \\
4 & 114 & 9 \\
5 & 113 & 9 \\
6 & 113 & 10 \\
\hline
\end{tabular}

\section{Plasma progesterone levels}

The mean plasma progesterone levels determined sequentially throughout pregnancy in five gilts (Table 1 , Nos 1 to 5) are shown in Text-fig. 1. The variability between individuals at all stages of gestation was fairly constant with the exception of the values obtained at Day 14 at which time one gilt (No. 1) had a very high plasma progesterone level $(41.0 \mathrm{ng} / \mathrm{ml})$ relative to the other four animals. The plasma progesterone concentration of this animal dropped to $21.9 \mathrm{ng} / \mathrm{ml}$ by Day 28 . It should be noted (Table 1 ) that this animal had a much larger litter than the others and the high plasma progesterone level on Day 14 may reflect the presence of a substantially greater number of corpora lutea in this sow. Although not statistically significant $(P=0.2)$, there would appear to be a downward trend in the mean plasma progesterone concentration from the Day- 14 mean peak oestrous cycle value of $21.9 \mathrm{ng} / \mathrm{ml}$ to the 28-day early pregnancy value of $13.0 \mathrm{ng} / \mathrm{ml}$. Although this decline can be largely attributed to the considerable drop, previously noted, that occurred in sow No. 1, another two of the five sows showed an appreciable drop in plasma progesterone concentration over this period. Between Day 28 and Day 91, the mean progesterone levels dropped steadily from a mean of $13.0 \mathrm{ng} / \mathrm{ml}$ to a mean of $10.4 \mathrm{ng} / \mathrm{ml}$ (not statistically significant). From Day 91, the proges- 
terone concentration commenced a pre-parturition decline to a mean level of $4.7 \mathrm{ng} / \mathrm{ml}$ on the day of parturition. A further sharp decline to a level of $<0.5 \mathrm{ng} / \mathrm{ml}$ was observed within $24 \mathrm{hr}$ of farrowing.

\section{Plasma unconjugated oestrogens}

The mean levels of unconjugated oestrone and oestradiol-17 $\beta$ during gestation and at parturition in pooled samples of plasma from the five gilts (Nos 1 to 5) are shown in Text-fig. 1. Unconjugated oestrone and oestradiol-17 $\beta$ were first present in measurable quantities at Day 80 and rose to peak values of

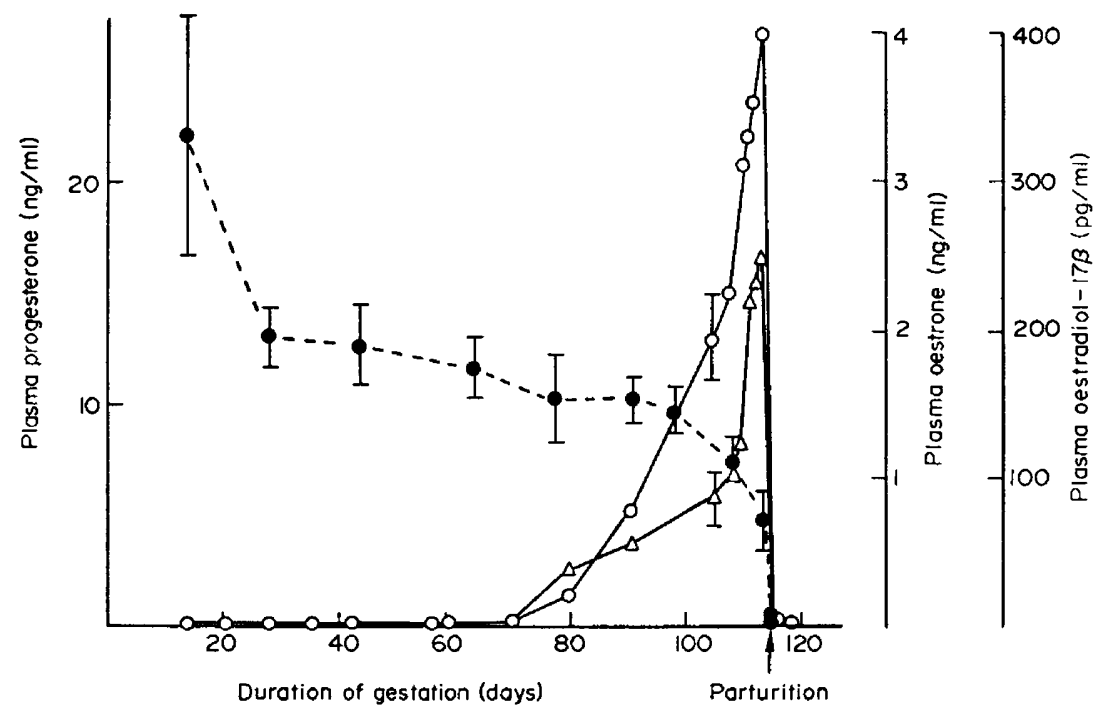

TEXT-FIG. 1. The concentration of progesterone ( $\bullet$, unconjugated oestrone $(\Delta)$ and oestradiol-17 $\beta(O)$ in the plasma of five gilts at implantation, throughout gestation, and at parturition. The vertical bars represent standard errors.

$2.5 \mathrm{ng}$ oestrone $/ \mathrm{ml}$ and $400 \mathrm{pg}$ oestradiol $-17 \beta / \mathrm{ml}$ just before parturition. Following parturition, the plasma oestrogen levels fell rapidly to $<15 \mathrm{pg} / \mathrm{ml}$.

Since these estimations were carried out on pooled aliquots of plasma, the levels of oestrone and oestradiol-17 $\beta$ in individual animals were determined at one fixed time, i.e. Day 105 of gestation, to assess the between-animal variability. The standard error of the means for oestrone and oestradiol-17 $\beta$ at this fixed point are shown in Text-fig. 1.

\section{Plasma oestrone sulphate}

Serial estimations of unconjugated oestrone and oestrone sulphate were carried out on the plasma of a single gilt (No. 6) sampled between Day 9 and parturition.

The results are shown in Text-fig. 2. The use of a semi-logarithmic scale enables changes at the lower end of the concentration span to be apparent. It is questionable whether the concentration of oestrone sulphate found at Day 9 is above the sensitivity of the method but there can be no doubt that 
the concentration of $60 \mathrm{pg} / \mathrm{ml}$ observed at Day 16 represents the beginning of a rise of oestrone sulphate in the maternal plasma which continues to a peak $>3 \mathrm{ng} / \mathrm{ml}$ sometime between Day 23 and Day 30. The plasma concentration of oestrone sulphate then declined sharply to a low value of $35 \mathrm{pg} / \mathrm{ml}$ around Day 46 before slowly rising again to attain a peak of $3.0 \mathrm{ng} / \mathrm{ml}$ on the day before parturition. Following parturition, the concentration of oestrone sulphate declined rapidly. Concurrent determination of unconjugated oestrone indicated that only marginally detectable levels of $15 \mathrm{pg} / \mathrm{ml}$ were present at the time (Day 23 and Day 30) when the concentration of oestrone sulphate was $3 \mathrm{ng} / \mathrm{ml}$. The plasma profile of unconjugated oestrone and oestradiol-17 $\beta$ in this individual was similar to that obtained with the pooled samples from the five gilts.

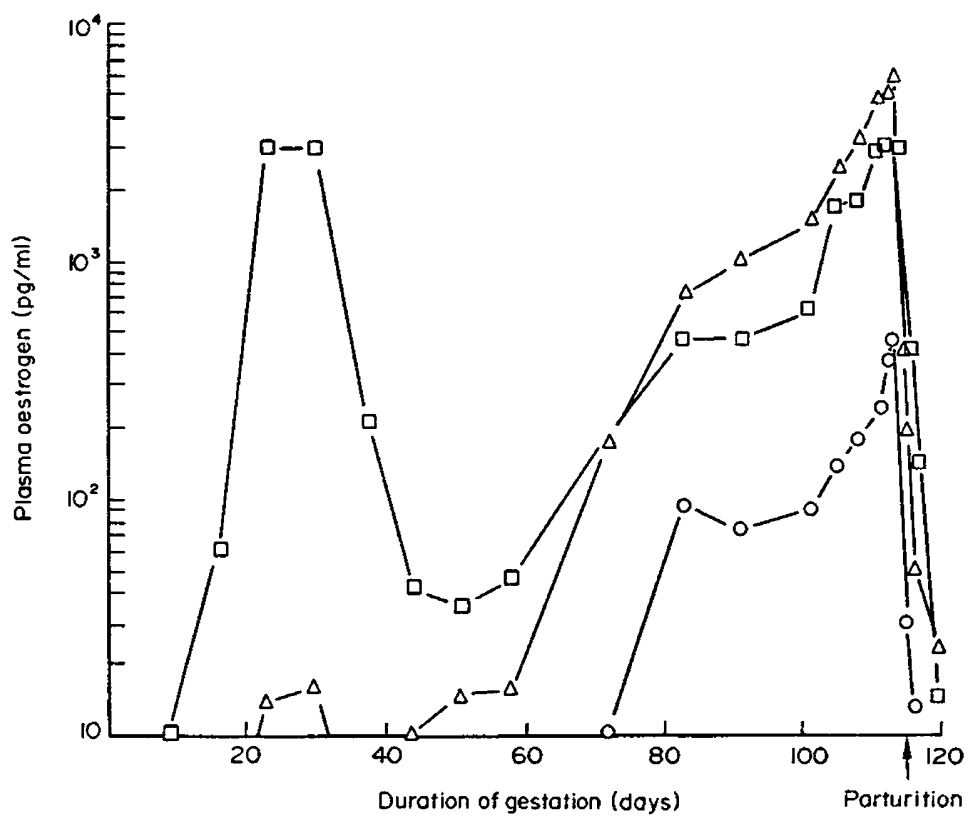

TexT-Fig. 2. The concentration of unconjugated oestrone $(\Delta)$, oestradiol-17 $\beta(0)$, and oestrone sulphate ( $\square$ ) in the plasma of a gilt at implantation, throughout gestation, and at parturition.

\section{DISCUSSION}

The mean level for the concentration of progesterone at 'mid-cycle' is in agreement with that reported by Stabenfeldt, Akins, Ewing \& Morrissette (1969), Tillson, Erb \& Niswender (1970) and by Shearer et al. (1972). During early pregnancy (Day 10 to Day 27), Tillson et al. (1970) found that the progesterone concentration of the plasma dropped from a mean of $26 \mathrm{ng} / \mathrm{ml}$ to $19 \mathrm{ng} / \mathrm{ml}$. In the present study, the mean level dropped from $21.9 \mathrm{ng} / \mathrm{ml}$ at Day 14 to $13.0 \mathrm{ng} / \mathrm{ml}$ at Day 28. Although this difference is not statistically significant because of the wide variation in values obtained at Day 14, it is striking and possibly had a biological significance. The observed downward trend between 
Day 28 and Day 98 and the acceleration of this downward trend after Day 98 until parturition is not in agreement with the changes reported by Shearer et al. (1972). These authors reported an increase in plasma progesterone between Day 93 and Day 112 followed by a decline until parturition on Day 117. The absence of a rise in maternal plasma progesterone in the pregnant sow, as observed in the pregnant woman (Short, 1961) and sheep (Bassett, Oxborrow, Smith \& Thorburn, 1969; Sarda et al., 1973), suggests that the conceptus does not contribute materially to the maternal pool of progesterone, i.e. the pregnant sow is dependent upon the corpora lutea for the maintenance of pregnancy (du Mesnil du Buisson \& Dauzier, 1957) and is similar to the pregnant cow in this respect (Donaldson, Bassett \& Thorburn, 1970; Stabenfeldt, Osburn \& Ewing, 1970; Robertson, 1972). A further resemblance to the cow is the relatively prolonged period of decline in the maternal plasma progesterone concentration before parturition, i.e. 15 to 20 days.

With the pooled plasma samples, no measureable amounts of unconjugated oestrone and of oestradiol-17 $\beta$ were present during the first half of gestation. The earliest detectable levels of both these oestrogens were observed between Day 70 and Day 80 of pregnancy. The plasma levels of both oestrogens then rose and attained a peak just before parturition. At the peak, the level of oestrone was approximately 16-fold greater than that of oestradiol-17 $\beta$. Work with acid hydrolysates of urine from pregnant sows (Velle, 1958; Lunaas, 1962; Rombauts, 1962; Raeside, 1963; Fèvre, Léglise \& Rombauts, 1968) has shown that the pattern of urinary excretion of total oestrone (conjugated plus unconjugated) during the second half of gestation follows the same pattern as that observed for unconjugated oestrone in plasma in the present study. All of these authors reported the presence of a substantial peak of urinary oestrone towards the end of the 1st month of gestation. In the present investigation, little if any unconjugated oestrone was detectable in the plasma at this time but substantial levels of a conjugated oestrone have been measured. Although the oestrone conjugate has not been definitely characterized, the evidence supports the view that it is principally oestrone sulphate. It is of considerable interest that at the time of the first peak of plasma oestrone sulphate (Day 23 to Day 30), when the level reached approximately $3 \mathrm{ng} / \mathrm{ml}$, the concentration of unconjugated oestrone was $15 \mathrm{pg} / \mathrm{ml}$ or less. The concentration of oestrone sulphate subsequently dropped to a low level around Day 50 before beginning a second rise. This rise followed very closely that observed for plasma oestrone and oestradiol-17 $\beta$ during the second half of pregnancy. Between Days 23 and 30, however, the ratio of the plasma levels of oestrone sulphate to oestrone was extremely high, approached unity around Day 70 and finally, at the peak concentration just before parturition, was approximately $1: 2$.

As to the source of the oestrone sulphate, Fèvre et al. (1968) have shown that neither the maternal ovaries nor the hypophysis was required for its production. We have found oestrone sulphate to be present in high concentration in the uterine vein and in allantoic fluid but not in ovarian venous blood at Day 28 of pregnancy (unpublished data). This observation agrees with that of Lunaas, Refsdal \& Schultz (1973) who reported the presence of an oestrone conjugate 
in uterine venous plasma and in allantoic fluid between Day 20 and Day 35. These results suggest that the oestrone sulphate present in maternal plasma at this time comes from the conceptus.

In view of the fact that it is probably the conceptuses that are synthesizing and secreting the oestrone sulphate, it is surprising that a detectable increase in the concentration of oestrone sulphate occurs in maternal plasma between Day 9 and Day 16. This is in good agreement with the observation of Perry, Heap \& Amoroso (1973) who have shown that Day-16 pig embryos can synthesize oestrogens whereas Day-10 embryos cannot. One discrepancy between the latter results and those now presented is that in their in-vitro system at Day 16, Perry et al. (1973) concluded that little or no conjugated oestrogens were being produced by the blastocyst whereas it is oestrone sulphate that is found in the maternal plasma at this time and in uterine plasma and in allantoic fluid at Day 28. Dhindsa \& Dziuk (1968), by destroying or removing embryos from one uterine horn in gilts at various times during early pregnancy, concluded that embryos must be present in both uterine horns between Days 10 to 12 for the continuation of pregnancy. The synthesis of oestrogens by the blastocysts at about this time and the subsequent associated rise in the level of maternal plasma oestrone sulphate may be a requirement for initiating locally the process of implantation in the uterus and, at the same time, informing the maternal endocrine system that conception has occurred. A similar conclusion was reached by Perry et al. (1973). At present, it is not clear whether the local effect on the uterus is brought about by a diffusion of unconjugated oestrogen from the blastocyst to the uterus with subsequent sulphation of the oestrogen within the uterine endometrium, as suggested by the findings of Perry et al. (1973). The oestrogen might be secreted by the blastocyst as oestrone sulphate with the subsequent conversion of part to a free biologically active oestrogen in the endometrium, as suggested by the findings of high concentrations of oestrone conjugate in the allantoic fluid between Day 20 and Day 35 (H. A. Robertson \& G. J. King, unpublished; Lunaas et al., 1973).

\section{ACKNOWLEDGMENTS}

We wish to record our indebtedness to $\mathrm{Mr} \mathrm{R}$. Durnford for his technical assistance in carrying out the analyses reported in this study and to $\mathrm{Dr} \mathrm{B}$. V. Caldwell for the oestradiol-17 $\beta$-hemisuccinyl BSA antiserum used in the oestrogen analyses. Contribution No. 526 of the Animal Research Institute.

\section{REFERENCES}

Ash, R. W., Banks, P., Bailes, G., Broad, S. \& Heap, R. B. (1973) Plasma oestrogen, progesterone and corticoid concentrations in the pregnant, parturient and lactating sow. J. Reprod. Fert. 33, 359.

Bassett, J. M., Oxborrow, T. J., Smith, I. D. \& Thorburn, G. D. (1969) Concentration of progesterone in the peripheral plasma of the pregnant ewe. 7 . Endocr. 45, 449.

Dhindsa, D. S. \& Diuzk, P.J. (1968) Effect on pregnancy in the pig after killing embryos or fetuses in one uterine horn in early gestation. 7. Anim. Sci. 27, 122.

Donaldson, L. E., Bassett, J. M. \& Thorburn, G. D. (1970) Peripheral plasma progesterone concentration of cows during puberty, oestrous cycles, pregnancy and lactation and the effects of undernutrition or exogenous oxytocin on progesterone concentration. $\mathcal{F}$. Endocr. 48, 599.

du Mesnil du Buisson, F. \& Dauzier, L. (1957) Influence de l'ovariectomie chez la truie pendant la gestation. C. r. Séanc. Soc. Biol. 151, 311. 
Fèvre, P., LÉglise, G. \& Rombauts, P. (1968) Du rôle de l'hypophyse et des ovaires dans la biosynthèse des oestrogènes au cours de la gestation chez la truie. Annls Biol. anim. Biochem. Biophys. $8,225$.

Johansson, E. D. B. (1969) Plasma levels of progesterone in pregnancy measured by a rapid competitive protein binding technique. Acta endocr., Copenh. 61, 607.

Loriaux, D. L., Ruder, H. J. \& Lipsett, M. B. (1971) The measurement of estrone sulfate in plasma. Steroids, 18, 463.

LunAAs, T. (1962) Urinary oestrogen levels in the sow during oestrous cycle and early pregnancy. F. Reprod. Fert. 4, 13.

LunaAs, T., Refsdal, A. O. \& Schultz, R. H. (1973) Conjugated oestrone in uterine vein blood during early pregnancy in the pig. Acta endocr., Copenh. Suppl. 177, 42.

Molokwu, E. G. I. \& WAGNER, W. G. (1973) Endocrine physiology of the puerperal sow. F. Anim. Sci. 36, 1158.

MURPhy, B. E. P. (1964) Application of the property of protein-binding to the assay of minute quantities of hormones and other substances. Nature, Lond. 201, 679.

Murphy, B. E. P. (1967) Some studies of the protein-binding of steroids and their application to the routine micro and ultramicro measurement of various steroids in body fluids by competitive protein-binding radio-assay. F. clin. Endocr. Metab. 27, 973.

Neil, J. D., Johansson, E. D. B., Datta, J. K. \& Knobil, E. (1967) Relationship between the plasma levels of luteinizing hormone and progesterone during the normal menstrual cycle. $\mathcal{F}$. clin. Endocr. Metab. 27, 1167.

Perry, J. S., Heap, R. B. \& Amoroso, E. C. (1973) Steroid hormone production by pig blastocysts. Nature, Lond. 245, 45.

RAESIDE, J. I. (1963) Urinary oestrogen secretion in the pig during pregnancy and parturition. $\mathcal{F}$. Reprod. Fert. 6, 427.

Robertson, H. A. (1972) Sequential changes in plasma progesterone in the cow during the estrous cycle, pregnancy, at parturition, and post-partum. Can. F. Anim. Sci. 52, 645.

Robertson, H. A. \& SARDA, I. R. (1971) A very early pregnancy test for mammals: its application to the cow, ewe and sow. F. Endocr. 49, 407.

Robertson, H. A., Smeaton, T. G. \& Durnford, R. (1972) A method for the extraction, separation and estimation of unconjugated estrone, estradiol-17 $\alpha$ and estradiol-17 $\beta$ in plasma. Steroids, 20,651 .

Rombauts, P. (1962) Excretion urinaire d'oestrogènes chez la truie pendant la gestation. Annls Biol. anim. Biochem. Biophys. 2, 151.

Sarda, I. R., Robertson, H. A. \& Smeaton, T. G. (1973) Sequential changes in plasma progesterone levels in the ewe during the estrous cycle, and during pregnancy in intact and ovariectomized sheep. Can. F. Anim. Sci. 53, 25.

Sarfaty, G. A. \& LipsetT, M. B. (1966) Separation of free and conjugated 11-deoxy-17-oxosteroids by thin-layer chromatography. Analyt. Biochem. 15, 184.

Shearer, I. J., Purvis, K., Jenkin, G. \& Haynes, N. B. (1972) Peripheral plasma progesterone and oestradiol-17 $\beta$ levels before and after puberty in gilts. F. Reprod. Fert. 30, 347.

Short, R. V. (1961) Progesterone. In Hormones in Blood, p. 379. Eds. C. H. Gray and A. L. Bacharach. Academic Press, London and New York.

Stabenfeldt, G. H., Akins, E. L., Ewing, L. L. \& Morrissette, M. G. (1969) Peripheral plasma progesterone levels in pigs during the oestrous cycle. $\mathcal{F}$. Reprod. Fert. 20, 443.

Stabenfeldt, G. H., Osburn, B. I. \& Ewing, L. L. (1970) Peripheral plasma progesterone levels in the cow during pregnancy and parturition. Am. F. Physiol. 218, 571.

Thorburn, G. D., BassetT, J. M. \& SMith, I. D. (1969) Progesterone concentration in the peripheral plasma of sheep during the oestrous cycle. F. Endocr. 45, 459.

Trulson, S. A., ERB, R. E. \& Niswender, G. D. (1970) Comparison of luteinizing hormone and progesterone in blood and metabolites of progesterone in urine of domestic sows during the estrous cycle and early pregnancy. F. Anim. Sci. 30, 795.

Tsang, G. P. W. (1974) Changes in plasma levels of estrone sulfate and estrone in the pregnant ewe around parturition. Steroids (in press).

Velie, W. (1958) Urinary estrogens of the pregnant sow. Am. F. vet. Res. 19, 405. 